\title{
BIOPSIJA PLUĆA U DIJAGNOZI INTERSTICIJALNIH PLUĆNIH OBOLJENJA
}

\author{
SURGICAL LUNG BIOPSY IN DIAGNOSIS OF INTERSTITIAL LUNG DISEASES
}

\author{
Aleksandra Lovrenski, Dragana Tegeltija, Slobodanka Pena Karan, Siniša Maksimović, \\ Svetlana Kašiković Lečić, Ivan Kuhajda
}

\begin{abstract}
Sažetak
Uvod: Biopsija pluća je hirurška metoda koja se koristi za postavljanje dijagnoze bolesti kod pacijenata sa difuznim bilateralnim plućnim lezijama ili lezijama nejasne etiologije u kojoj su sve druge dijagnostičke metode iscrpljene.

Cilj rada: Analiza materijala dobijenog biopsijom pluća u cilju dobijanja definitivne dijagnoze.

Materijal i metode: Ispitivanje je obuhvatilo 42 pacijenta kod kojih je u periodu od 2007. do 2017. godine na Institutu za plućne bolesti Vojvodine u Sremskoj Kamenici, urađena biopsija pluća. Analizirani su: starosna dob pacijenata, pol, simptomi bolesti, lokalizacija promena, tip biopsije, mesto uzimanja bioptičkog materijala kao i histološke karakteristike promena u plućima.

Rezultati: Od 42 pacijenta kojima je urađena biopsija pluća, otvorena biopsija po Claassen-u rađena je kod 45\% pacijenata, kod 38\% otvorena biopsija po Maassen-u, dok je kod 17\% materijal uzet VATSom. Najčešće mesto biopsije bila je lingula, u 49\% slučajeva, zatim gornji režanj (36\%), srednji režanj (9\%), donji režanj (4\%) i baza (2\%). Dijagnostikovane su: nespecifične fibrozne promene u 22\% pacijenata, UIP u 16\%, PLCH u 16\%, sarkoidoza u 14\%, emfizem u 7\%, hipersenzitivni pneumonitis u 7\%, NSIP u 4\%, organizirajuća pneumonija, aktinomikoza, pneumokonioza zubnih tehničara, LAM, LIP, DIP i ACIF u po $2 \%$ pacijenata. Kod svih pacijenata sa patohistološkim nalazom nespecifičnih fibroznih promena materijal je uzet iz lingule.

Zaključak: Saradnja radiologa, kliničkog lekara, patologa i hirurga je neophodna i ima za cilj postavljanje konačne dijagnoze plućnih oboljenja u materijalu dobijenom biopsijom pluća.
\end{abstract}

Ključne reči: VATS, otvorena biopsija pluća, intersticijalne bolesti, dijagnoza

\section{Uvod}

Veliki broj oboljenja pluća se može dijagnostikovati različitim metodama, ali su u mnogim situacijama biopsija i patohistološki nalaz neophodni za konačnu dijagnozu i pristup terapiji. Materijal za patohistološki pregled se već decenijama unazad uzima putem minitorakotomije ili uz pomoć medijastinoskopa, međutim u poslednjih dvadesetak godina, biopsija pluća počela se izvoditi videoasistiranom torakoskopskom procedurom (VATS). Primena videoasistirane torakoskopske biopsije pluća, kao manje invazivne hirurške procedure, dovela je do porasta broja urađenih biopsija pluća, jer je prihvatljivija kako za pacijenta, tako i za lekara kliničara i hirurga [1]. Bolja vizuelizacija pleuralnog prostora, mogućnost biopsije različitih delova pluća, manji postoperativni bol, brži oporavak kao i manji i estetski prihvatljiviji ožiljak neke su od prednosti VATS biopsije pluća. Najčešća anatomska lokalizacija za uzimanje biopsije pluća je decenijama bila srednji režanj i lingula. Mnoga istraživanja smatraju da su lingula i srednji režanj precenjeni kao anatomske lokalizacije za standardno uzimanje biopsije pluća, zbog čestih fibroznih ili vaskularnih promena, te da je potrebno uzimati uzorke i iz drugih režnjeva oba pluća. Zbog toga se aktuelno preporučuje da se za biopsiju izbegavaju delovi pluća sa lokalizovanom fibrozom ili ožiljnim tkivnom. Savetuje se uzimanje bioptata iz više režnjeva na osnovu radiološkog nalaza visokorezolutivne kompjuterizovane tomografije (HRCT) grudnog koša. Takođe, dijagnoza se lakše i precizije postavlja ukoliko se biopsija pluća izvodi u ranijim fazama, a ne u terminalnoj fazi bolesti [2]. Uzimanje više uzoraka pluća sa različitih režnjeva omogućava dobijanje preciznije dijagnoze [3]. Sa 
druge strane, neki autori smatraju da nema razlike $u$ dobijanju adekvatne dijagnoze ukoliko se uzme jedna reprezentativna biopsija $u$ odnosu na više biopsija sa različitih delova pluća [4]. Odluku o optimalnom mestu uzimanja biopsija pluća potrebno je da donesu zajedno hirurg, pulmolog, radiolog i patolog [5]. Smatra se da je adekvatna veličina uzorka pluća za patohistološki pregled oko $4 \mathrm{~cm}$ i da ne treba uzimati samo rubne i subpleuralne delove pluća, već ići u dubinu parenhima $3-5 \mathrm{~cm}$ [6]. Uzete bioptate pluća kod bolesnika sa sumnjom na intersticijumsku bolest pluća, tj. IPF, nije potrebno poslati na ex tempore pregled, već samo na definitivni patohistološki pregled. U slučaju sumnje i na malignitet, potrebno je uzorak poslati i na ex tempore analizu [6]. Otvorena biopsija pluća se preporučuje kao korisna procedura za slučajeve koji pokazuju difuzne bilateralne plućne lezije, ili lezije nejasne etiologije u kojoj su sve druge dijagnostičke metode neadekvatne. Epidemiološki podaci ukazuju na to da se mortalitet u prvih 30 dana posle biopsije pluća kreće 3-5\% kumulativno. Međutim, ukoliko se izuzmu visoko rizični pacijenti - oni koji su već na mehaničkoj ventilaciji, na imunosupresivnoj terapiji i sa egzarcebacijom bolesti, procenat mortaliteta se kreće između 1,5-3\% [7]. Iako se u današnje vreme teži neinvazivnim metodama dijagnostike ili što manje invazivnim procedurama, biopsija pluća je najpouzdanija metoda za uzimanje materijala za patohistološku analizu kao zlatni standard postavljanja konačne dijagnoze različitih oboljenja.

\section{Materijal i metode}

Ispitivanje je obuhvatilo 42 pacijenta kod kojih je u periodu od 2007. do 2017. godine na Institutu za plućne bolesti Vojvodine u Sremskoj Kamenici, urađena biopsija pluća radi dobijanja adekvatnog materijala za patohistološku analizu sa ciljem dijagnostikovanja različitih oboljenja pluća.

Izvođenje biopsije pluća pomoću medijastinoskopa spada u minimalno invazivnu hiruršku proceduru. Incizija dužine oko $20 \mathrm{~mm}$ se pravi $\mathrm{u} \mathrm{V}$ međurebarnom prostoru $\mathrm{u}$ prednjoj aksilarnoj liniji. Po otvaranju pleure medijastinoskop se plasira u pleuralni prostor. Potom se izvodi inspekcija pluća, pri čemu je limitirana vizuelizacija celog pluća. Atraumatskom hvatalicom se uzima vrh lingule ili deo srednjeg režnja i zatim pažljivo izvuče van toraksa gde se resecira sa TA steplerom ili se prešije koncem (Slika 1). Nakon plasmana drena i kompletne reekspanzije pluća, ukoliko nema vazdušnog gubitka, dren se može odmah izvaditi (biopsija pluća po Maassen-u), ili se može ostaviti i ukloniti nekoliko sati posle operacije (biopsija pluća po Klassen-u). Za uzimanje uzoraka pluća potrebno je koristiti atraumatske hvatalice kako ne bi došlo do mehaničkog oštećenja tkiva pluća. Takođe, važno je maksimalno izbeći pojavu gubitka vazduha na resekcionoj marginisteplerskoj liniji. Postoperativni gubitak vazduha se javlja kod oko $12 \%$ pacijenata, što zahteva višednevnu drenažu pleure i produženu hospitalizaciju pacijenta, a sledstveno tome veći rizik za razvoj postoperativnih komplikacija, od empijema pleure do egzarcebacije osnovne bolesti, respiratorne insuficijencije i letalnog ishoda.

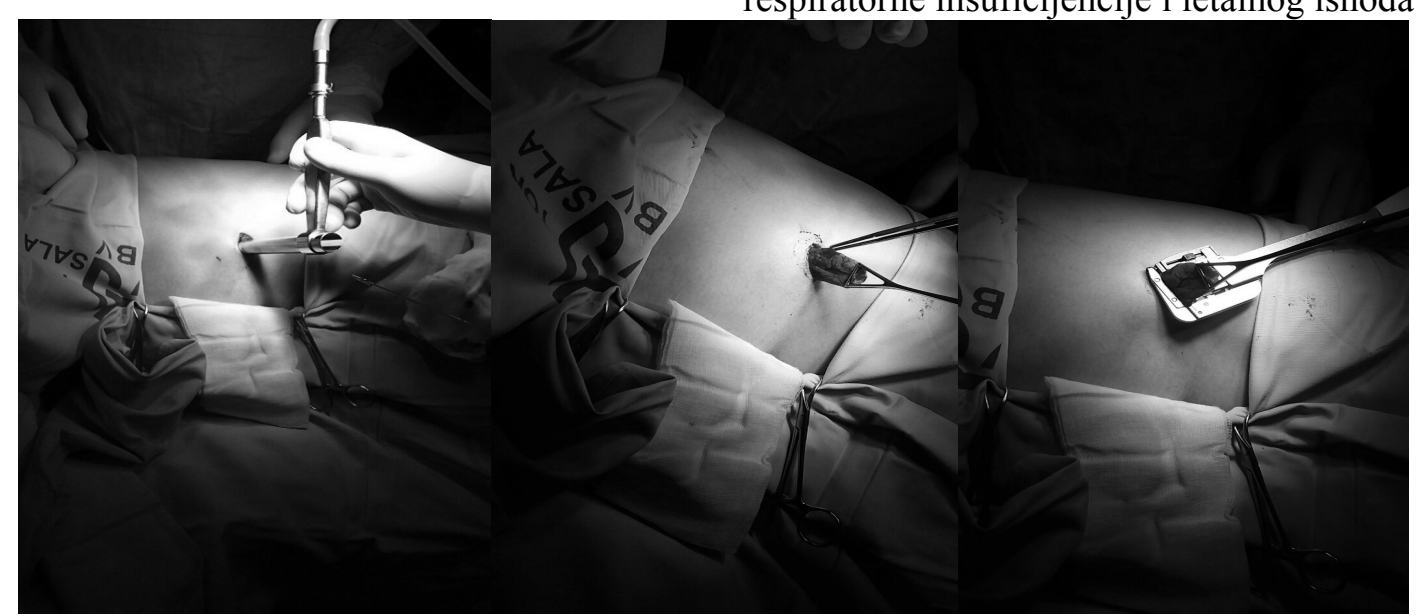

Slika 1. Plasman medijastinoskopa radi inspekcije pluća, izvlačenje dela pluća i resekcija pomoću steplera 
Otvorenom biopsijom dobijen deo plućnog tkiva je preko noći ostavljen u 10\% formalinu, a u pojedinim slučajevima pre potapanja u bočicu sa formalinom uz pomoć šprica je ubrizgavan formalin $\mathrm{u}$ tkivo u cilju reekspanzije plućnog parenhima i njegove bolje fiksacije. Nakon pažljivog uklanjanja metalih kopči sa ivica preparata tkivo je serijski rezano i u celosti uzimano za patohistološku analizu. Nakon kalupljenja u parafinu uzorci su sečeni mikrotomom na tkivne isečke debljine 4 mikrona, a potom bojeni hematoksilin-eozin (HE) metodom. U nekim slučajevima korišćene su dodatne tehnike poput histohemijskih (Perls, Mallory) i imunohistohemijskih bojenja (CD1a, CD68, S-100).

Analizirani su: pol, starosna dob pacijenata, simptomi bolesti, tip biopsije, mesto uzimanja bioptičkog materijala kao i patohistološke karakteristike promena u plućima.

\section{Rezultati}

Od 42 pacijenta kojima je urađena biopsija pluća $25(60 \%)$ su bile osobe ženskog pola, dok je 17 (40\%) osoba bilo muškog pola. Najmlađi pacijent uključen u istraživanje imao je 24 godine, a najstariji 70.

Iz obrađenih anamnestičkih podataka dobili smo informaciju da je kod 27 (64\%) pacijenata bila prisutna jedna ili više tegoba. Kod 19 (34\%) pacijenata bio je prisutan suv kašalj, kod $2(4 \%)$ kašalj i iskašljavanje, kod $1(2 \%)$ hemoptizije, kod $16(29 \%)$ slabost i malaksalost, kod $13(22 \%)$ dispneja, kod 2 (4\%) promuklost i kod $3(5 \%)$ bolovi u grudnom košu, dok čak 15 (36\%) pacijenata nije imalo tegoba.

Pušenje kao faktor rizika za nastanak respiratornih oboljenja bilo je prisutno kod 19 (45\%) pacijenata, dok su svi pacijenti sa dijagnostikovanom PLCH bili dugogodišnji pušači.

Analiziranjem hirurških metoda kojima je prikupljen materijal za patohistološku obradu, dobijamo podatak da je kod 19 (45\%) pacijenata rađena otvorena biopsija pluća po Claassen-u, kod 16 (38\%) otvorena biopsija po Maassen-u, dok je kod 7 (17\%) pacijenata materijal uzet VATS-om.

Najčešće mesto biopsije bila je lingula, u 22 (49\%) slučaja, zatim gornji režanj u 16 (36\%), srednji režanj u 4 (9\%), donji režanj u 2 (4\%) i baza u $1(2 \%)$ pacijenta.
Najčešći patohistološki nalaz ukazivao je na nespecifične fibrozne promene u 10 (22\%) pacijenata, dok su od ostalih oboljenja dijagnostikovani: uobičajena intersticijalna pneumonija (engl. Usual interstitial pneumonia UIP) (Slika 2) u 7 slučajeva (16\%), plućna histiocitoza Langerhansovih ćelija (engl. pulmonary Langerhans cell histiocytosis - PLCH) (Slika 3) u 7 $(16 \%)$ pacijenata, sarkoidoza u $6(14 \%)$, emfizem u 3 (7\%), hipersenzitivni pneumonitis u $3(7 \%)$, nespecifična intersticijalna pneumonija (engl. nonspecific interstitial pneumonia - NSIP) u 2 (4\%), organizirajuća pneumonija, aktinomikoza, pneumokonioza zubnih tehničara (engl. dental technician pneumoconiosis), limfangioleiomiomatoza (engl. lymphangioleiomyomatosis - LAM), limfocitna intersticijalna pneumonija (engl. lymphocytic interstitial pneumonia - LIP), ACIF (engl. Airwaycentered idiopathic fibrosis) (Slika 4) (Slika 12.) i deskvamativna intesticijalna pneumonija (engl. Desquamative interstitial pneumonia - DIP) (Slika 5) u po $1(2 \%)$ pacijenta (Tabela 1). Kod svih pacijenata sa patohistološkim nalazom nespecifičnih fibroznih promena materijal je uzet iz lingule. $U$ tri pacijenta biopsija je ponovljena, a materijal uzet sa drugog mesta iz pluća (gornji režanj i donji režanj), te je upravo to drugo mesto biopsije doprinelo postavljanju tačne dijagnoze (sarkoidoza, DIP i UIP). Rezultati ukazuju da su biopsijom lingule dobijene sledeće dijagnoze: nespecifične fibrozne promene u 10 (45\%) uzoraka, UIP u 5 (23\%), PLCH u 3 (13\%), sarkoidoza u 2 (9\%), aktinomikoza i emfizem u po 1 (5\%) uzorak; biopsijom gornjeg režnja: PLCH u 4 (25\%) uzorka, hipersenzitivni pneumonitis i sarkoidoza u po 3 (19\%), NSIP u 2 (13\%), dental technician pneumoconiosis, LAM, LIP i DIP u po 1 (6\%) uzorak; srednjeg režnja: emfizem u $2(50 \%)$ uzorka, ACIF i UIP u po 1 (25\%) uzorak; donjeg: UIP i organizirajuća pneumonija u po $1(50 \%)$ uzorak; i baze sarkoidoza u 1 uzorku. 


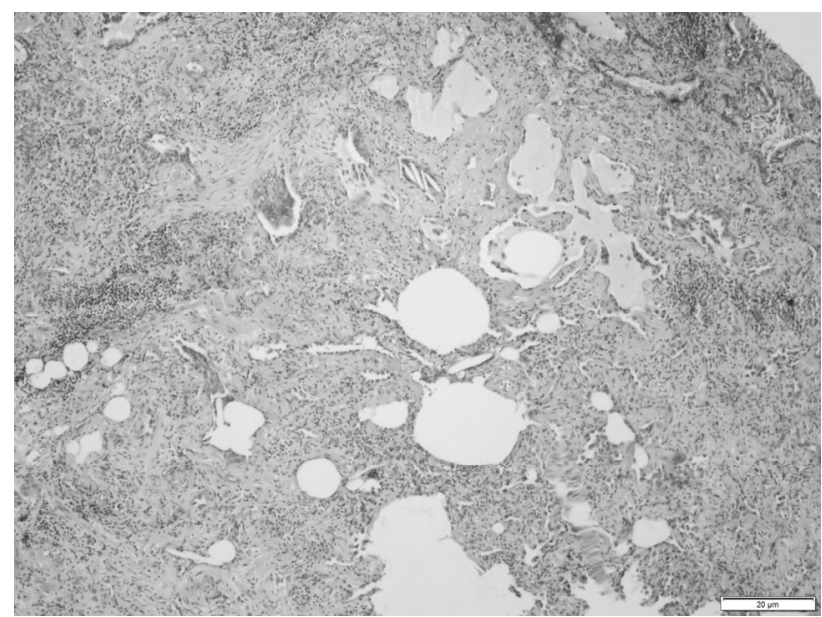

Slika 2. UIP - umnoženo vezivo u intersticijumu, hiperplazija pneumocita, cistični prostori ispunjeni sa sluzi i fibroblastični fokusi, H\&E $\times 40$.

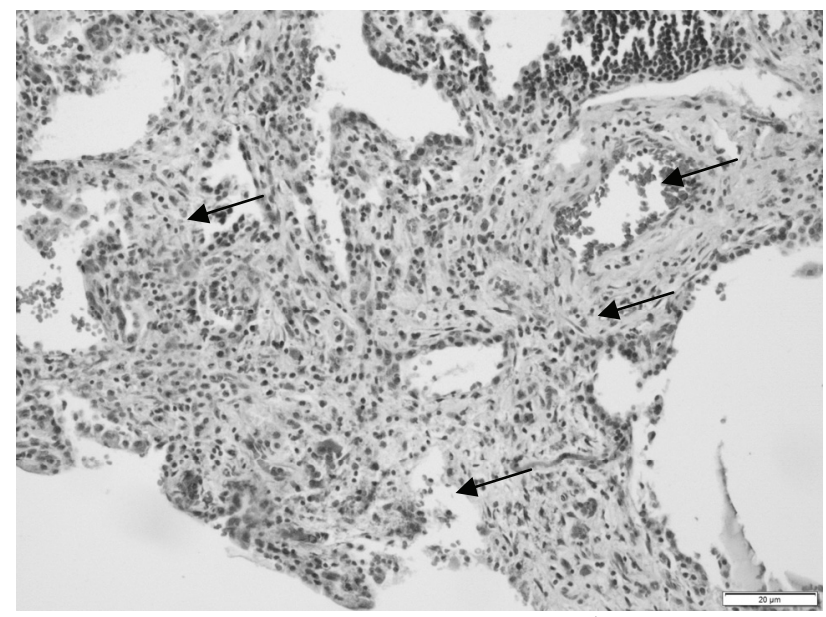

Slika 3. PLCH - proširenje intersticiłna sa nakupinama eozinofilnih granulocita i Langerhansovih ćelija (strelice), $H \& E \times 100$.

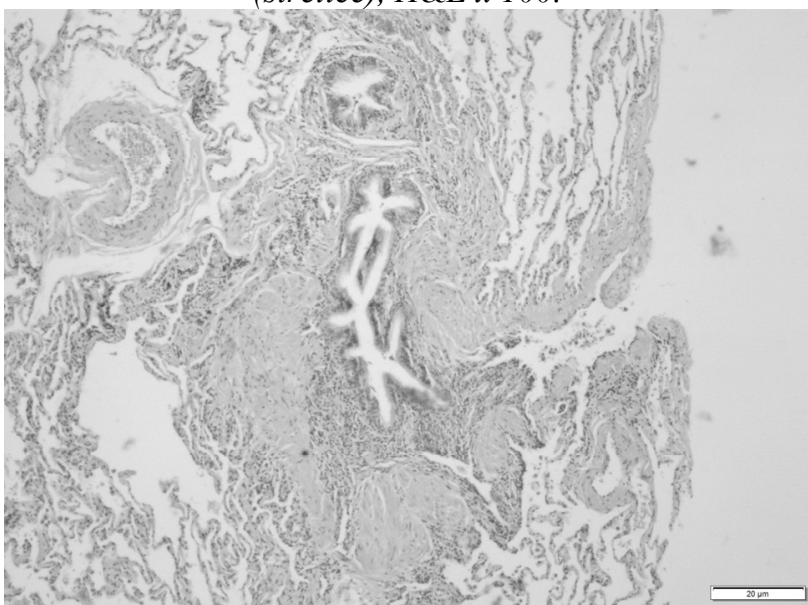

Slika 4. ACIF, airway fibrosis and chronic interstitial lung disease, $H \& E \times 40$.

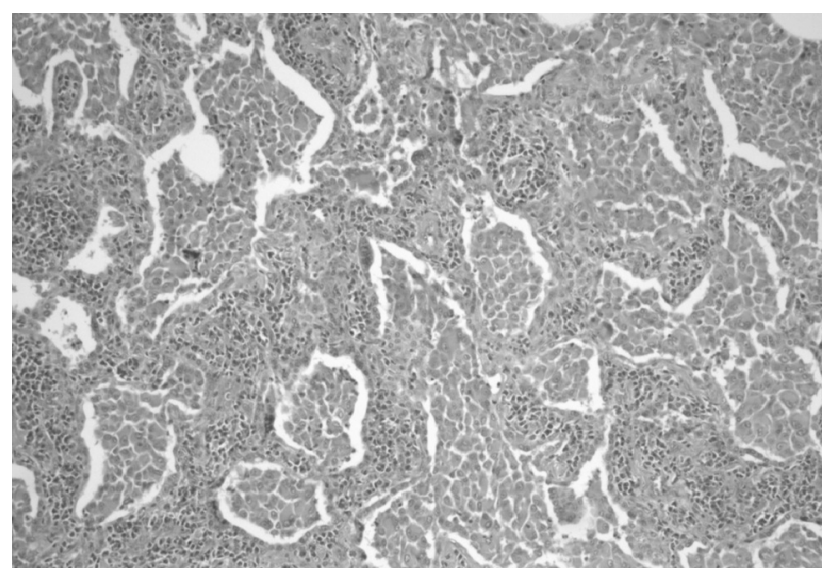

Slika 5. DIP - pušački makrofagi u alveolama, $H \& E x$ 100

Tabela 1. Prikaz patohistoloških dijagnoza i njihove zastupljenosti među pacijentima.

\begin{tabular}{|l|l|}
\hline Dijagnoza & $\begin{array}{l}\text { Broj pacijenata } \\
\mathrm{n}(\%)\end{array}$ \\
\hline PLCH & $7(16 \%)$ \\
\hline UIP & $7(16 \%)$ \\
\hline Sarkoidoza & $6(14 \%)$ \\
\hline Emfizem & $3(7 \%)$ \\
\hline Hipersenzitivni pneumonitis & $3(7 \%)$ \\
\hline NSIP & $2(4 \%)$ \\
\hline Organizirajuća pneumonija & $1(2 \%)$ \\
\hline Aktinomikoza & $1(2 \%)$ \\
\hline LAM & $1(2 \%)$ \\
\hline LIP & $1(2 \%)$ \\
\hline Dental technician pnemoconiosis & $1(2 \%)$ \\
\hline ACIF & $1(2 \%)$ \\
\hline DIP & $1(2 \%)$ \\
\hline Nespecifične fibrozne promene & $10(22 \%)$ \\
\hline
\end{tabular}

\section{Diskusija}

Biopsija pluća kao hirurška metoda koja omogućava uzimanje materijala za patohistološki pregled interesantna je tema za mnoga istraživanja koja se bave dijagnostikom plućnih oboljenja. $\mathrm{Na}$ Institutu za plućne bolesti Vojvodine zabeležena su za poslednjih deset godina 42 slučaja biopsija pluća u svrhu dobijanja konačne dijagnoze plućnog oboljenja. U dosadašnjim studijama veći broj biopsija zabeležen je u populaciji ženskog pola, te se sa ovim istraživanjima slažu i naši rezultati koji sugerišu da je od analiziranih slučajeva veća zastupljenost ženskog pola sa udelom $60 \%$. Osvrtom na starosnu dob dobija se podatak da ona ne čini kontraindikaciju za izvođenje biopsije, te je najmađi pacijent imao 24, a najstariji 70 godina. Klinički simptomi su raznovrsni, kroz istraživanja beleži se 
različita učestalost određenih tegoba. U našem istraživanju veći je procenat (64\%) pacijenata koji su imali jednu ili više tegoba. Najviše je onih koji su se žalili na suv kašalj (34\%), pored toga u velikom procentu bili su zastupljeni slabost i malaksalost $(29 \%)$ i dispneja (22\%), dok su u manjem procentu bili prisutni bolovi u grudnom košu (5\%), kašalj i iskašljavanje (4\%), promuklost (4\%) i hemoptizije $(2 \%)$. Iz obrađenih anamnestičkih podataka beleži se podatak da su $45 \%$ pacijenata bili dugogodišnji pušači, gde najveći udeo (37\%) čine oni sa dijagnostikovanim PLCH, što govori u prilog uske povezanosti PLCH sa pušenjem. U dostupnim literaturnim navodima prikazan je i jedan slučaj PLCH dijagnoze kod pacijenta koji nije bio pušač, međutim veći je broj istraživanja kod kojih je pušenje faktor rizika, sa čim se slažu i naši rezultati $[8,9]$.

Etiološka dijagnoza difuznih infiltrativnih bolesti pluća često zahteva biopsiju pluća, koja obezbeđuje definitivnu patološku dijagnozu u većini pacijenata [10]. Glavno pitanje tada je '’Iz kog lobusa pluća bi trebalo obezbediti materijal za patohistološku analizu?'. Naime, u svetu sve poznatija hirurška metoda svakako jeste VATS jer obezbeđuje dobar pregled cele pleuralne šupljine, te stoga i bolju selekciju mesta za biopsiju [11]. Među hirurškim tehnikama $u$ našem radu, najčešći tip operacije kojim je prikupljan materijal za patohistološki pregled predstavlja otvorena biopsija pluća, a zatim u manjem procentu VATS. Poznatu činjenicu čine podaci o velikoj učestalosti komplikacija i smrti nakon biopsija pluća, međutim studija Chiee Lee i saradnika beleži samo nekoliko postoperativnih komplikacija, a nijedna smrt nije povezana direktno sa procedurom [11]. Upravo sa ovim podacima slaže se $i$ naše istraživanje gde nije zabeležen nijedan smrtni ishod, kao ni komplikacija uzrokovana biopsijom. Akcenat istraživanja svakako pored patohistološke dijagnoze predstavlja i mesto biopsije što jeste tema mnogih istraživanja. Naši podaci ukazuju da je najčešće mesto biopsije bila lingula (49\%), što je u najvećem procentu doprinelo nemogućnosti postavljanja tačne dijagnoze zbog velike količine fibroznih promena koje su karakteristične za to mesto u prilog čemu govore $\mathrm{i}$ neke dosta ranije studije koje navode da biopsija lingule i srednjeg režnja daje histološki beznačajne nalaze te bi se trebala izbegavati [12]. Patohistološki nalaz predstavlja zlatni standard $\mathrm{u}$ postavljanju dijagnoze plućnih oboljenja, shodno tome veoma je važno da materijal tokom biopsije bude uzet sa što adekvatnijeg mesta u plućima kako bi patolog imao jasnu sliku i mogućnost postavljanja konačne dijagnoze. U našem istraživanju među patološkim nalazima najčešće su beležene nespecifične fibrozne promene $(22 \%)$, zatim u manjem procentu PLCH $(16 \%)$, UIP $(18 \%)$, sarkoidoza $(14 \%)$, emfizem (7\%), hipersenzitivni pneumonitis (7\%), NSIP (4\%), organizirajuća pneumonija, aktinomikoza, dental technicans pneumoconiosis, ACIF, DIP, LAM i LIP (2\%). Od posebnog značaja je podatak koji ukazuje da je materijal u kojem su dokazane nespecifične fibrozne promene u svim slučajevima vodio poreklo iz lingule. Kod tri pacijenta pored uzorka uzetog iz lingule koji je pokazao nespecifične fibrozne promene, uzeti su i uzorci sa drugog mesta u plućima i upravo su oni omogućili postavljanje prave dijagnoze. Kod dva pacijenta uzet je materijal iz gornjeg režnja i njegovom analizom dobijena je dijagnoza sarkoidoze i DIP-a, dok je kod trećeg pacijenta materijal uzet iz donjeg režnja čime je postavljena dijagnoza UIP-a. Ovi podaci, kao i veliki broj istraživanja u svetu sugerišu da je $u$ postavljanju dijagnoze plućnih oboljenja preko potrebno promeniti dosadašnju praksu uzimanja materijala iz lingule, te akcenat staviti na uzimanje uzoraka sa drugih mesta u plućima u kojima su u manjoj meri prisutne fibrozne promene. Još pre mnogo godina istraživanja u svetu rađena su na temu uzimanja biopsije sa prethodno radiološki određenog mesta u plućima, te je upravo takvo istraživanje sprovedeno od strane Chechani i saradnika pokazalo da uzimanje multiplih plućnih isečaka tokom biopsije pluća nije potrebno, već da je jedan bioptički uzorak uzet iz reprezentativnog područja verifikovanog radiološki na HRCT-u celishodan i jednako efektivan [12].

Shodno svemu navedenom, saradnja radiologa, kliničkog lekara, patologa i hirurga, svakako je i više nego potrebna, te u budućnosti treba sprovesti bolju organizaciju u smeru timskog rada, koji kao jedini cilj ima postavljanje konačne dijagnoze plućnih oboljenja biopsijom pluća i primenu adekvatne terapije.

\section{Literatura}

1. Kayatta MO, Ahmed S, Hammel JA, Fernandez F, Pickens A, Miller D et al. Surgical biopsy of suspected interstitial lung disease is superior to 
radiographic diagnosis. Ann Thorac Surg 2013;96:399-402.

2. Bradley B, Branley HM, Egan JJ, Greaves MS, Hansell DM, Harrison NK et al. Interstitial lung disease guideline: the British Thoracic Society in collaboration with the Thoracic Society of Australia and New Zealand and the Irish Thoracic Society. Thorax 2008;63 Suppl 5:1-58.

3. Monaghan H, Wells AU, Colby TV, du Bois RM, Hansell DM, Nicholson AG. Prognostic implications of histologic patterns in multiple surgical biopsies from patients with idiopathic interstitial pneumonias. Chest 2004;125(2):522-6.

4. Qureshi RA, Ahmed TA, Grayson AD, Soorae AS, Drakeley MJ, Page RD. Does lung biopsy help patients with interstitial lung disease? Eur J Cardiothorac Surg 2002;21:621-6.

5. Halkos ME, Gal AA, Kerendi F, Miller DL, Miller Jr JI. Role of thoracic surgeon in the diagnosis of idiopathic interstitial lung disease. Ann Thorac Surg 2005;79:2172-9.

6. Bradley B, Branley HM, Egan JJ, Greaves MS, Hansell DM, Harrison NK et al. Interstitial lung disease guideline: the British Thoracic Society in collaboration with the Thoracic Society of Australia and New Zealand and the Irish Thoracic Society. Thorax 2008;63 Suppl 5:1-58.
7. Han Q, Luo Q, Xie JX, Wu LL, Liao LY, Zhang $\mathrm{XX}$, et al. Diagnostic yield and postoperative mortality associated with surgical lung biopsy for evaluation of interstitial lung disease: a systematic review and meta-analysis. J Thorac Cardiovasc Surg 2015;149:1394-401.

8. Fernandes L, Vadala R, Menezes A. ScienceDirect Rare interstitial lung disease : Pulmonary Langerhans Cell Histiocytosis in a young non smoking Indian female. Indian $\mathrm{J}$ Tuberc 2015;62(1):46-9.

9. Vassallo R, Ryu HJ, Schroeder RD, Decker AP, Limper HA. Clinical outcomes of pulmonary Langerhans'-cell histiocytosis in adultsM. N Engl J Med 2002;346(7):484-90. Blackhall V, Asif M, Renieri A, Civitelli S, Kirk A, Jilaihawi A, et al. The role of surgical lung biopsy in the management of interstitial lung disease : experience from a single institution in the UK. ICVTS 2017;17:253-7.

10. Lee $\mathrm{Y}, \mathrm{Wu} \mathrm{C}$, Hsu $\mathrm{H}$, Huang $\mathrm{P}$, Chang $\mathrm{Y}$. Experience of 196 patients. J Thorac Cardiovasc Surg 2016;48:1453-1461.

11. Chechani V, Landreneau RJ, Shaikh SS. Open Lung Biopsy for Diffuse Infiltrative Lung Disease. Ann Thorac Surg 1992;54(2):296-300.

\section{Summary}

Introduction: Lung biopsy is a surgical method for obtaining material for pathohistological analysis used in patients with diffuse bilateral pulmonary lesions or lesions of unclear etiology in which other diagnostic methods are not indicated.

Goal: To analyze material obtained by lung biopsy in order to get final diagnosis.

Material and methods: From 2007. to 2017. at Institute for pulmonary diseases of Vojvodina in Sremska Kamenica lung biopsy was performed in 42 patients. There were analyzed: patients age, gender, symptoms of disease, localization of changes, type of biopsy, place of taking bioptic material and pathohistological diagnosis.

Results: Of the 42 patients, open biopsy by Claassen was done in 45\% patients, in 38\% patients was done open biopsy by Maassen, while in 17\% of them material was taken by VATS. The most common place for biopsy was lingula in 49\% cases, then upper lobe 36\%, middle lobe $9 \%$, lower lobe $4 \%$ and base in 2\%. There were diagnosed: nonspecific fibrotic changes in 22\% patients, UIP in 16\%, PLCH in $16 \%$, sarcoidosis in 14\%, emphysema in 7\%, hypersensitive pneumonitis in 7\%, NSIP in 4\%, organizing pneumonia, actinomycosis, pneumoconiosis of dental technicians, LAM, LIP, DIP and ACIF 2\% patients. In all patients with pathohistological findings of nonspecific fibrotic changes material was taken from lingula.

Conclusion: Cooperation of radiologist, clinician, pathologist and surgeon is necessary and it has goal to set a final diagnosis of pulmonary disease in material obtained by lung biopsy.

Keywords: VATS, Open lung biopsy, Interstitial diseases, Diagnosis

Adresa autora za korespondenciju:

Aleksandra Lovrenski,

Univerzitet u Novom Sadu, Medicinski fakultet, Novi Sad, Srbija 
Put doktora Goldmana 4,

21204, Sremska Kamenica, Srbija 00381668805321 ,

aleksandra.lovrenski@mf.uns.ac.rs, 